UDC 94(477.8):364-3:061.1“1941/1944"

DOI: $10.24919 / 2519-058 x .14 .197186$

\title{
Vitalina DANYLCHUK
}

PhD (History), Associate Professor of Social and Humanitarian Education Department of Rivne Regional Institute of Postgraduate Pedagogical Education, 74 Viacheslav Chornovol Street, Rivne, Ukraine, postal code 33028 (vitalina.-@ukr.net)

ORCID: http://orcid.org/0000-0002-7176-7386

\section{Andriy LEVDER}

PhD (Education), Associate Professor of History Department, Head of The International Economic and the Humanities History Department Academician Stepan Demianchuk University, 4 Stepan Demianchuk Street, Rivne, Ukraine, postal code 33027 (levderandry2@ukr.net)

ORCID: http://orcid.org/0000-0002-7140-4622

\section{Вімаліна ДАНИЛЬЧУК}

кандидат історичних наук, доцент кафедри суспільно-гуманітарної освіти Рівненського обласного інституту післядипломної педагогічної освіти, вул. В. Чорновола, 74, м. Рівне, Україна, індекс 33028 (vitalina.-@ukr.net)

\section{Андрій ЛЕВДЕР}

кандидат педагогічних наук, дочент кафедри історії, завідувач кафедри історії Міжнародного економіко-гуманітарного університету імені академіка Степана Дем'янчука, вул. С. Дем'янчука, 4, м. Рівне, Украӥна, індекс 33027 (levderandry2@ukr.net)

Бібліографічний опис статті: Danylchuk,V. \& Levder, A. (2020). Social support of the population of Volyn and Rivne regions by Local committees to help in the period of the Nazi occupation. Skhidnoievropeiskyi Istorychnyi Visnyk [East European Historical Bulletin], 14, 144-152. doi: 10.24919/2519-058x.14.197186

\section{SOCIAL SUPPORT OF THE POPULATION OF VOLYN AND RIVNE REGIONS BY LOCAL COMMITTEES TO HELP IN THE PERIOD OF THE NAZI OCCUPATION}

\begin{abstract}
The purpose of the research is to investigate the problem of the social support for the population, who lived during the Nazi occupation in Volyn and Rivne regions by local aid committees. The methodology of the research is based on the general scientific and special historical methods. The work is based on the principles of historicism, scientific objectivity and the problem chronological approach. The scientific novelty is that for the first time on the basis of the archival documents and the press of that period, the basic principles of auxiliary institutions' functioning in the territory of Volyn and Rivne regions were investigated comprehensively: purpose, tasks, structure, directions of activity, sources of financing, relations with the occupying power. The Conclusions. It has been traced that the first organizations of this type began to appear in the region in the beginning of the 1941 and operated until January 1944. The support/ auxiliary committees network, which actively cooperated with each other, branched out sufficiently. The Local District Self-help Institutions coordinated the work of all committees, which exercised their powers through the District, City and Village Committees and were
\end{abstract}


funded through: the self-taxation by employees of local institutions and organizations, the educational institutions, the voluntary donations, the membership dues, the membership fees, etc. In addition to Ukrainian, there were Polish aid committees. It has been investigated that these non-governmental organizations have taken care of the orphanages, kindergartens, schools, homes for the disabled, homeless shelters, maintained dining rooms, and organized kitchens. They provided food, clothing, heating materials, medicines, funds for those who needed it most - the sick, the widows, the orphans, the elderly, the single, the poor, the incapacitated, the prisoners' of war, the families whose members were taken to work in Germany and more. It has been proved that the activity of the institutions was controlled by the occupying power.

Key words: local self-help institution, public organisation, the Nazi occupation regime, Rivne region, Volyn region.

\title{
СОЦІАЛЬНА ПІДТРИМКА НАСЕЛЕННЯ ВОЛИНСЬКОЇ ТА РІВНЕНСЬКОЇ ОБЛАСТЕЙ МІСЦЕВИМИ КОМІТЕТАМИ ДОПОМОГИ В ПЕРІОД НАЦИСТСЬКОЇ ОКУПАЦІї
}

\begin{abstract}
Анотація. Мета дослідження - проаналізувати проблему соціальної підтримки населення, яке проживало в період нацистської окупації на території Волинської та Рівненської областей, місцевими комітетами допомоги. Методологію дослідження складають загальнонаукові та спеціальні історичні методи. В основу розвідки покладено принципи історизму, наукової об'єктивності та проблемно-хронологічний підхід. Наукова новизна полягає у тому, що вперше, на основі архівних документів, тогочасної преси, комплексно досліджено основні принципи функиіонування допомогових інституиій на території Волинської та Рівненської областей: мета, завдання, структура, напрями діяльності, джерела фінансування, взаємовідносини з окупаиійною владою. Висновки. Простежено, що перші організацї̈ такого типу почали з'являтися в регіоні на початку осені 1941 р. і діяли до січня 1944 р. Мережа допомогових комітетів, які активно співпрацювали, була достатньо розгалужена. Координували роботу усіх комітетів Окружні місцеві інституиії самодопомоги, котрі свої повноваження реалізовували через Районні, Міські та Сільські комітети, які фінансувалися через: самооподаткування співробітників місцеевих установ і організацій, закладів освіти, добровільні пожертви, иленські внески, прибутки з постановки вистав тощо. Окрім українських, діяли польські допомогові комітети. Досліджено, що вказані громадські організаиії піклувалися про дитячі будинки, садки, иколи, будинки інвалідів, притулки для бездомних, утримували їдальні, організовували кухні. Вони забезпечували продуктами харчування, одягом, опалювальними матеріалами, ліками, коштами тих, хто цього найбільше потребував, -хворих, вдів, сиріт, людей похилого віку, одиноких, убогих, нездатних до праці, військовополонених, сім'ї, членів яких вивезли на роботу до Німеччини тощьо. Доведено, що діяльність інституцій контролювала окупаційна влада.
\end{abstract}

Ключові слова: місцева інституція самодопомоги, громадська організаиія, нацистський окупаиійний режим, Рівненська область, Волинська область.

The Problem Statement. World War II and the Nazi occupation regime led to the emergence of a large number of socially vulnerable population groups, who could not solve the day-to-day problems on their own. Therefore, there was the ugent need for public support for the needy residents of different regions of Ukraine. In view of this, from the summer to the fall of 1941, the support committees of various levels began to emerge, on which such a charitable mission was entrusted.

The Analysis of Sources and Recent Researches. In the historiography, the self-help institutions functioning issue in the territory of "Volyn-Podillya" district under the Nazi occupation, was investigated fragmentarily and mostly in the context of the social and political processes consideration that took place in Ukraine at that time, the local authorities' activities, the health care of the state analysis, the cities' and regions' everyday life. The Ukrainian 
historians' achievements, in a certain aspect, are represented by the works written by B. Zek (Zek, 2017), B. Kytsak (Kytsak, 2017), K. Kurylyshyn (Kurylyshyn, 2010), O. Lysenko (Lysenko, 2003), S. Stelnykovych (Stelnykovych, 2013), H. Stefaniuk (Stefaniuk, 2014), V. Shaikan (Shaikan, 2005) and others. A monographs by K. Berkhoff (Berkhoff, 2011) and T. Snyder (Snyder, 2011) are important for understanding the problem. Therefore, a number of aspects concerning the organization of public care of Volyn and Rivne regions by the local support committees, its effectiveness, public support, and so on, remain unaddressed. In view of this, the article was based on the archival documents and materials.

The purpose of the article is to analyze the issue of social support of the population, who lived during the Nazi occupation in the Volyn and Rivne regions, by the local aid committees.

The Statement of the Basic Material. In Volyn and Rivne region territories, the aid institutions were formed on the basis of the special orders, A. Rosenberg, the Reich Minister, E. Koch, the Reich Commissar of Ukraine and the Gebit Commissioners and at the local authorities' initiative orders. The committees were entrusted with the charitable tasks for the health and public care of the poor. In particular, they pledged to take care of the educational institutions, orphanages, kindergartens, homeless shelters, homes for the disabled, etc., to provide food, clothing, heating materials, medicines, funds for those, who was the most in need - the sick, the widows, the orphans, the homeless people, the elderly, the pregnant women, the single, the poor, the incapacitated, the prisoners of war, as well as the family whose members were taken to work in Germany (SARR, f. S-72, d. 1, c. 1, pp. 1-16; SARR, f. S-82, d. 1, c. 1, pp. 1-31; SAVR, f. S-1, d. 7, pp. 13, 39; SAVR, f. S-2, d. 2, c. 10, pp. 2-12). Since charity in those days was an important factor in the Ukrainians' national solidarity (Lysenko, 2003, pp. 101-111), so the aid institutions' activity was constantly under the control of the occupying authorities.

The Assistance Committees were guided by the statutes, regulations, which were somewhat different in form and content, but contained identical provisions regarding the key aspects of the activity. The constituent documents outlined the basic rules and principles for the committees' functioning: name, location, distribution areas, purpose, objectives, structure, areas of activity, staff requirements, conditions for acquiring and withdrawing membership, sources of funding; societies, etc. A mandatory attribute was a stamp and a special bank account (SAVR, f. S-2, d. 2, c. 10, pp. 2-12; SARR, f. S-72, d. 1, c. 1, pp. 2, 12-13, 27-29).

The first self-help organizations began to appear in the region in the beginning of the 1941, in autumn. Thus, in September, the Ukrainian Aid Committee (UAD), which consisted of 45 members, began to work in Lutsk. The heads of this organization were alternately: M. Zaleskyi, B. Biletskyi (until July 1943), V. Herovskyi (SAVR, f. S-2, d. 2, c. 10, p. 2; SSA SSU-Lutsk, c. 7889, pp. 21-23, 47).

At the beginning of October in 1941, a district "The Poor Winter Aid Committee" was organized in Kostopil, which since May 1, 1942, was reorganized into the "Ukrainian People's Aid" (SARR, f. S-72, d. 1, c. 1, pp. 1-3, 29, 31), which operated until September 11, 1942, a time of reformatting, based on the orders of the occupying power, into the "Local Self-help Committee" (LSC), which operated under that name until 1944 (SARR , f. S-72, d. 1, p. 17, p. 16; SARR, f. S-82, d. 1, c. 7, pp. 7-9). The Committee in Kostopil was headed by: H. Rybak, since May 1942 - by M. Mozhovyi. The Board included: F. Stepanyuk, D. Novoseletskyi, S. Orlinskyi, V. Novytska. Each person was responsible for a particular direction of the institution's work. (SARR, f. S-72, d. 1, c. 7, p. 16).

On the $26^{\text {th }}$ of November in 1941, the "Winter Aid Committee" was established in Sarnakh. Initially, it operated only within the city limits, and after its renaming into the 
"Ukrainian District Aid Committee" on the $11^{\text {th }}$ of February in 1942, the influence sphere extended to the territory of the entire Sarny district. I. Marynyuk was the District Aid Committee Chairman, V. Teodorovych - the Secretary, Y. Dobrovolskyi - the Treasurer (SARR, f. S-77, d. 1, c. 1, p. 4).

The Aid Committee was formed in Kamin-Kashyrskyi on the $5^{\text {th }}$ of December in 1941. O. Velihodskyi was the Chairman, E. Karanovych - the Secretary, V. Vynyavskyi - the Treasurer, F. Kolenda and M. Radostovets were appointed as the agents of the prisoners' affairs (SARR, f. S-77, d. 1, c. 1, p. 6). The Ukrainian Self-Helping Committee started to operate in Dubno from 1942 (Dopomozhimo, 1943, p. 2) and many other settlements in the region. (Dopomozhimo, 1943, p. 2).

The District Local Self-help Institution (DLSI) was created, known as "Unity" (Yednist) in order to control and coordinate the work of regional committees operating in the territory of Rivne region (SARR, f. S-72, d. 1, p. 1, pp. 1-3). The above-mentioned organization could also be found in the documents under the following name: the "Ukrainian Central Assistance Committee" (SARR, f. S-77, d. 1, c. 1, p. 1). V. Beyer, the Reich Commissar, appointed L. Stupnitsky as the Head of the organisation and Kh. Kononenko - as the business manager. The were also the following Institutions: the "Advisory Board and the Aid Board" (SARR, f. S-72, d. 1, c. 1, p. 12).

The DLSI Charter provided for the operation of three divisions: the Main Division, the Labor Group I, and the Labor Group II. The Main Department was in charge of the organizational, economic, financial matters, record keeping, statistics, correspondence with institutions and organizations, with district, city departments and other districts, collection of the material resources for the institution's tasks accomplishment, search of the prisoners and missing persons, etc.

The Labor Group I was responsible for collecting products, clothing, footwear, furniture, supplies and other means, distributing them, catering in public kitchens, arranging homes for the people in need, creating kindergartens and crèches for babies, disabled people and the elderly, etc. The Labor Group II competence was the following: health care in the settlements, nurses and other sanitary aids training organization, arrangement of the appropriate institutions for the sick, wounded and prisoners (SARR, f. S-72, d. 1, c. 1, pp. 12, 13; Pystso, 2010, pp. 25-27).

DLSI vested its authority in the District Local Self-help Institutions (DLSI), which operated in each district, the Municipal Local Self-help Institutions (MLSI) with the offices in the cities where the City Councils were located, and the Village Local Self-help Institutions (VLSI) provided for each village in the area. The District Local Self-help Institutions and the Municipal Local Self-help Institutions Heads were appointed by the Head of the District Institution in liaison with the business manager. The District and City Aid Committees performed the tasks assigned to them by DLSI. The above-mentioned organizations had the right to dispose only $50 \%$ of the collected property.

At the head of the Village Local Self-help Institution (VLSI) was the Trustee ("Muzh Doviry"), approved by the the District Local Self-help Institution (DLSI) and by the District Head. The Trustee ("Muzh Doviry") had a Council, which consisted of 5 people, held various fundraisers, considered applications for the assistance, and with the help of the District Institution represented the needs of the township to the District Committee. Village Local Selfhelp Institution (VLSI) had no right to dispose the funds or the collected property (SARR, f. S-72, d. 1, c. 1, pp. 12, 13). 
In 1942 on the $16^{\text {th }}$ of December the District Local Self-help Institutions (DLSI) was formed in Rivne (Rivne, 4 Lysenka St.), headed by Y. Lychyk, and Ye. Polyak performed the duties of the secretary. The Village Local Self-help Institution Village Local Self-help Institution (VLSI) started operating in Rivne region from the $1^{\text {st }}$ of January, 1943, and there were 54 organizations operating in the area already in May of the same year, which were providing the financial support to 49 families (126 people). (SARR, f. S-72, d. 1, c. 3, pp. 14, 34, 42).

In addition to the Ukrainian Aid Institutions, there were also the Polish Aid Institutions. In September 1941, at the initiative of Bishop A. Szelążek, a Polish Aid Committee was organized in Lutsk. In July 1942, under Z. Khmelnytskyi's control there were 11 employees in the staff. Owing to the Committee's efforts the orphanages, elders and hospitals for the sick were organized. In total, the Committee provided helped ans suported over 8,000 people. The Committee began to work particularly active in 1943 (SAVR, f. S-1, d. 1, c. 23, p. 10; SAVR, f. S-2, d. 2, c. 49, p. 19; SAVR, f. S-1, d. 1, c. 7, pp. 58-59).

"The Polish Aid Committee for the Poor", which took care of the "citizens of the Polish nationality", operated in Kostopil. As a result, the local Ukrainian Committee made the final decision to suspend the aid issuance to the Poles, who appealed to on the $19^{\text {th }}$ of June in 1943 (SARR, f. S-82, d. 1, p. 8, p. 11). Due to the fact that the Polish population, who lived in the district did not participate in organizing the voluntary meetings, which were aimed at helping the poor properly, also facilitated the situation. According to the written records, the Roman Catholic parish issued only 739 rubles ('karbovantsiv') out of the revenue funds in January of 1943, while the Committee had already issued 8250 rubles ('karbovantsiv') to the Poles by that time (SARR, f. S-82, d. 1, c. 1, p. 11).

According to the archival materials, a sufficiently extensive network of such organistions was formed with the occupying authorities' permission since the autumn of 1941 up till the winter of 1942 in Volyn and Rivne regions. Moreover, the above-mentioned organisations cooperated with each other actively in order to improve the daily life of the local residents, while demonstrating a sufficiently high level of the social cohesion.

The main sources of financing for the new public entities were: the employees' local institutions, organizations', educational institutions' self-taxation, the voluntary donations, the membership fees, income from the performances. The charitable activity, in particular, the population's voluntary donations, was included in the aid institutions' financing (SARR, f. S-72, d. 1, c. 1, p. 2; SARR, f. S-2, d. 2, c. 10, pp. 3-6).

The local businesses and institutions employees' voluntary taxation were the most important sources of the budget filling. For instance, L. Stupnytskyi and M. Zalesskyi were addressing to the Heads of the districts, cities, as well as organizations with such requests repeatedly, and for the most cases their requirements were fullfiled. Some institutions, with the consent of their employees, set fixed interest rates that were the subject to monthly payroll deductions in favor of the UAC, sometimesthe organisations practised the so-called "one day donations" (SARR, f. S-72, d. 1, c. 1, pp. 1, 5).

The Aid Committee's archival documents include the information about such voluntary donations from the various levels' employees (rural, urban, district, district), banking, post, telegraph, railway, educational, cultural, health, workshops, mills, plants, factories, printing houses and other institutions operating in the territory of Volyn and Rivne regions during the Nazi occupation.

Hence, "The Poor Winter Aid Committee" received some sum of money from different sources, for example, 4640,81 rubles from Kostopil District Administration employees' September salaries (5\% of each) in several stages, 2302,43 rubles - from the Local Administration 
employees', 106,08 rubles - from the City Administration in October 1941. Therefore, by the end of October, considering the contributions of the post and telegraph staff -1102.83 rubles, medical personnel - 944.60 and other working people, the Committee had more than 19 thousand rubles. According to the District Bank in Kostopil, the balance of the Local District Aid Committee was 92579.44 rubles on the $1^{\text {st }}$ of January 1 in 1942 (SARR, f. S-82, d. 1, c. 3, pp. 1-4; SARR, f. S-82, d. 1, c. 4, pp. 1-43), and on the $1^{\text {st }}$ of December in $1943-$ 20 956,03 rubles (SARR, f. S-82, d. 1, c. 17, pp. 1, 14).

Due to their difficulties, complicated by the closure of the educational institutions, the educators provided the assistance, help and support to the public organizations. On the $10^{\text {th }}$ of October in 1941, Kostopil school teachers transferred 880 rubles from salaries, which they received in September (SARR, f. S-82, d. 1, c. 3, p. 3). The Head of school in the village Tynne, Rivne region sent a letter to the Local Government Head, confirming the teachers' consent to voluntarily donate $1 \%$ of each monthly salary in favor of the District Local Selfhelp Institutions on the $23^{\text {rd }}$ of December in 1942 (SARR, f. S-72, d. 1, c. 1, p. 8). A similar letter came from the teachers of the village Omelyana, where it was stated that they were ready for a systematic monthly $2 \%$ payroll donation on the $30^{\text {th }}$ of December in 1942 (SARR, f. S-72, d. 1, c. 10, p. 64).

Despite their own disadvantage caused by the ruthless tax and financial policies of the occupying power, the people of the region did not remain apart from other people's problems and provided assistance to one another to the best of their ability. Therefore, we trace the number of voluntary individual contributions of the region's residents to the Committees' needs, the size of which ranged from 1 to 200 rubles (SARR, f. S-82, d. 1, c. 3, p. 1-12; SARR, f. S-72, d. 1, c. 10, p. 13).

The work of the clergy and religious communities was valuable in organizing support actions for the benefit of the needy. In particular, in February 1942 there were collected 493 rubles in Derazhnenskyi Church (SARR, f. S-82, d. 1, c. 1, p. 11; SARR, f. S-82, d. 1, c. 4, pp. 44, 45). In the same month, a Congregation of Christians of the Evangelical Faith in Stepan handed over to the Aid Committee 800 rubles (SARR, f. S-82, d. 1, p. 9, p. 29). In February 1943, 1500 rubles were raised by the "Reformed Church in Stepan" (SARR, f. S-82, d. 1, c. 17, p. 4). On the $8^{\text {th }}$ of May, 1943, the parishioners of the settlements Marynyn and Lyudvypil deposited 400 rubles into the Committee's bank account (SARR, f. S-82, d. 1 , c. 5 , p. 23 ).

During the Christmas holidays, with the Reich's Commissar permission numerous performances were organised: carols, 'schedirvka', gatherings in temples and on the streets, and the funds raised went to benefit self-help Committees. That's why, Kostopil District managed to collect 50 872,73 rubles in January of the 1943. (SARR, f. S-82, d. 1, c. 5, p. 19). In addition, the institutions together with the community arranged the Christmas trees trimming for the poor children, who, whenever possible, presented small gifts during the holiday (things, products, bakery, etc.) (SARR, f. S-72, d. 1, c. 1, p. 5). The charity campaigns were also held during the Easter holidays (SARR, f. S-72, d. 1, c. 3, p. 14, 34).

In order to supplement the budget of the organizations, and at the same time to eliminate psychological strain and rest, local communities, with the consent of the District Commissioners, organized performances. In particular, to this end, on the $11^{\text {th }}$ of December in 1941 in the town of Rozhysche staged the play "Natalka Poltavka" (SAVR, f. S-2, d. 2, c. 11, p. 5). Staging the drama in 5 acts "Coming Back from Siberia", initiated by Bereznivskyi District Winter Aid Committee, took place in the following settlements: Mokvyn, Malynsk, Berezne and Lyudwypil (SARR, f. S-82, d. 1, c. 1, p. 5). 
In the absence of funds, taking care of the most socially vulnerable population, people shared what they had: they gave potatoes, beetroots, carrots, beans, flour, barley, rye, oats, cereals, onions, eggs, bread, as well as: clothes, shoes, bedding, etc. (SARR, f. S-72, d. 1, c. 10 , p. 15, 29; SSA SSU-Lutsk, c. 7889 , p. 47). Thus, according to the archival materials, the UAC in Lutsk distributed " $3879 \mathrm{~kg}$ of flour, $37 \mathrm{~kg}$ of butter, $690 \mathrm{~kg}$ of cereals, $9.5 \mathrm{~kg}$ of honey, 14607 eggs, $175 \mathrm{~kg}$ of fat" and other products on the $1^{\text {st }}$ of January in 1942. In addition, 825 sets of underwear, 400 pieces of men's outerwear and 240 pieces of women's outwear, 202 pillows, 21 featherbeds, 46 blankets were distributed to the people in need (Ukrainskyi, 1942, p. 3).

Moreover, with the helpof the local press - "Volyn", "Kostopilski Visti", "The Voice of Sarnenshchyna", "The Ukrainian Voice", self-help institutions conducted an active awareness-raising campaign among the population. They placed requests, called for the "voluntary assemblies" for the people in need, later on published the gratitude notes for the assistance provided, and periodically published materials on Local Committees establishment and activity.

Along with raising money, food and essentials, these public institutions were involved in distributing assistance to those people in need. But beforehands, there were the requests' consideration and the financial status of needy citizens who sought support for the (in) ability to provide themselves with the most necessary means for life. A "Map of the Citizens' Material Survey" was drawn up, which provided the basic information about the person: surname, name, patronymic, date and place of birth, health status with whom he / she resides, from which he or she has any property, or has relatives (if yes, their financial status was indicated) and the Trustte's "Muzh Doviry" conclusion that the person needed help and what kind of help was also defined (SARR, f. S-72, d. 1, c. 8, pp. 1-70). Taking into account the analysis of such document, we can make infer that both in the villages and in the cities, during the Nazi occupation, there were a considerable number of the poor, sick, elderly, minors, who, due to various factors, could not, or were unable to work, abstained from begging . Therefore, the Aid Committees examined the situation of everyone who needed support and determined who and what should be given priority. Everything depended on the situation in which a person was, later on the one-time or monthly assistance was issued.

The monthly assistance was provided, according to the accepted guidelines, based on the calculation: for one dependent $40-50$ rubles, for 2-3 dependents -60 rubles, for 4-6 dependents - 70 rubles, for 6 or more - 80 rubles (SARR, f. S-1, d. 1, p. 7, pp. 46-49). However, the Committee members considered each case individually, so the amount of payments could fluctuate. Thus, in November 1941, the Local Committee paid in some stages to the poor residents of Kostopil and the eponymous district about 2500 rubles (in the amount of 40 to 100 rubles). (SARR, f. S-82, d. 1, c. 3, pp. 5-10). У січні 1944 p. 67 нужденним видали 7180 крб (SARR, f. S-82, d. 1, c. 19, pp. 1-4). In total, from October of the 1941 up till May of the 1942, Kostopil Committee managed to support 397 people on a monthly basis, who lived in the area and the needed material assistance and one-time assistance to 267 people. Concerning one-time assistance, the biggest sum of money was allocated for the treatment - from 200 to 500 rubles, for the purchase of the orphan products -500 rubles, for people, who suffer from fire - from 300 to 500 rubles, for burials - 100-150 rubles, etc. (SARR, f. S-82, d. 1, c. 1, pp. 27-30; SARR, f. S-82, d. 1, c. 18, p. 5). In most cases, the complex assistance was provided (food, necessary things, money) (SARR, f. S-72, d. 1, c. 11, pp. 100, 126).

In 1942-1943 "the harvest period" (from the $1^{\text {st }}$ of July up till the $1^{\text {st }}$ of October), the assistance to the poor but able-bodied population was discontinued as their participation in the "bread and vegetables harvest" was foreseen as an opportunity to earn money (SARR, f. S-82, d. 1, c. 8, pp. 11-13). 
The Aid Committees were maintenaning the dining rooms, organising the cheap or free kitchens as it was the important area of their work. Thus, the UAC in Lutsk kept the Ukrainian House dining room, which was considered to be one of the best in the city, and its income was transferred to the agreed public organisation's bank account. A number of people were served food there, for example, 150 Ukrainian soldiers, 110 civilians and 40-50 people visited on a daily basis individually. A person could have breakfast and dinner at the Ukrainian House dining room for only3 rubles, and having lunch could cost for 6 rubles (SAVR, f. S-2, d. 2, c. 10, pp. 2-6; Levchenko, 1943, p. 3). There was also a free of charge kitchen in the city, which in 1941 served daily 250-300 free dinners, as a result, lots of residents were saved from hunger. The kitchen, which served up to 100 free lunches daily, was organized by the Ukrainian District Aid Committee in Sarny (SARR, f. S-77, d. 1, c. 1, p. 4).

The aid institutions also maintained kindergartens. In particular, from the $30^{\text {th }}$ of September in 1942, a kindergarten was transferred to the capital of the "Local Self-help Committee" (LSC) in Kostopil. (SARR, f. S-82, d. 1, c. 7, p. 39). There were 25 children in the kindergarten during that time. The monthly payment for the child was 40 rubles, the poor parents paid half of the price or were exempted. Due to the lack of warm clothing and shoes during the cold days, the kindergarten was visited only by 10 of them, so it was decided to close it in the winter period from the $1^{\text {st }}$ of December, since it was irrational to keep 3 staff members for such a number of kids (SARR, f. S-82, d. 1, c. 8, p. 4, 22; SARR, f. S-82, d. 1, c. 11, p. 33). The kindergarten, which attended by 40 children, was supported by the UAC in Lutsk (SAVR, f. S-1, d. 1, c. 7, p. 41). In order to provide these institutions with the staff, the Committee organized "one-month kindergarten courses", which completed 30 girls successfully in 1942 (from the $26^{\text {th }}$ of May up till the $1^{\text {st }}$ of July ) (Kurs, 1942, p. 4). Similar one- and two-month courses were organized by Rivne Regional Aid Institution (SARR, f. S-72, d. 1, c. 3, p. 12).

An important area of the LSC work was the custody of prisoners of war, their relatives, as well as the search of those mobilized to the army and missing persons, in connection with the receipt of their respective requests and requests. In addition, the self-help Committees supported prisoners of war, who were in the camps of Rivne, Sarny, and Lutsk with food, medicine, and arranged kitchens for them. Thus, in the winter of the $1941-1942$, the LSC in Lutsk served the prisoners up to 500 bowls of hot soup daily (SARR, f. S-77, d. 1, c. 2, pp. 1-70; SARR, f. S-72, d. 1, c. 3, p. 16).

The Conclusions. All things to be considered, the self-help committees of various levels operated throughout Volyn and Rivne regions during the Nazi occupation period. These were legal non-governmental organizations, controlled by the occupying power, that solved residents' numerous problems as the locals were facing them daily, they were the desparate people in need. An analysis of their work showed a sufficiently high level of public cohesion in helping one another. However, taking into account, the low financial and material capacity of the population caused by the conditions of the Nazi occupation regime, these humanitarian institutions could not meet the needs of all those people in need.

In further research, it would be advisable to consider the activities of aid institutions in the territory of the Reich Commissariat, which was called "Ukraine", as well as to analyze the members' staff of these organizations.

Acknowledgments. The authors express gratitude to the staff of the archival institutions whose documents were used in the article, the members of the editorial board for the consultations provided during the preparation of the article for printing.

Financing. The authors received no financial support for the proposed work, authorship, and publication of this article. 


\section{BIBLIOGRAPHY}

Berkhoff, K. (2011). Zhnyva rozpachu. Zhyttia i smert v Ukraini pid natsystskoiu vladoiu [Harvest of despair. Life and death in Ukraine under Nazi rule]. Kyiv, 456 p. [in Ukrainian]

Haluzevyi derzhavnyi arkhiv Sluzhby bezpeky Ukrainy, m. Lutsk. [Sectoral State Archive of the Security Service of Ukraine - SSA SSU-Lutsk]

Danylchuk, V. (2013). Reikhskomisariat - Reikhovi: ukraintsi z Rivnenshchyny na prymusovykh robotakh $v$ Avstrii ta Nimechchyni [Reich Commissariat - to Reichs: Ukrainians from Rivne region for forced labor in Austria and Germany]. Rivne, 282 p. [in Ukrainian]

Derzhavnyi arkhiv Volynskoi oblasti [State Archive of Volyn Region - SAVR]

Derzhavnyi arkhiv Rivnenskoi oblasti [State Archives of Rivne region-SARR]

Dopomozhimo, (1943). Dopomozhimo sobi sami [Let us help ourselves]. Volyn, 30 veresnia. [in Ukrainian]

Zek, B. (2017). Lutsk u roky natsystskoi okupatsii (1941 - 1944) [Lutsk during the Nazi occupation (1941 - 1944)]. Lutsk, 421 p. [in Ukrainian]

Kytsak, B. (2017). Diialnist humanitarnykh orhanizatsii u haluzi medychnoho obsluhovuvannia naselennia v raikhskomisariati "Ukraina" u 1941 - 1944 rr. [Activity of humanitarian organizations in the field of public health services in the Reich Commissariat "Ukraine" in 1941 - 1944]. Aktualni problemy humanitarnykh ta pryrodnychykh nauk: materialy IV Mizhnarodnoi naukovo-praktychnoi konferentsii [Topical problems of the humanities and natural sciences: materials of the IV International scientific-practical conference] (pp. 83-85). [in Ukrainian]

Komitet, (1941). Komitet Zymovoi Dopomohy v Kostopoli [Winter Aid Committee in Kostopil]. Kostopilski visti, 26 zhovtnia. [in Ukrainian]

Kurylyshyn, K. (2010). Ukrainske zhyttia v umovakh nimetskoi okupatsii (1939 - 1944 rr.): za materialamy ukrainomovnoi lehalnoi presy [Ukrainian Life in the conditions of the German Occupation (1939 - 1944)]. Lviv, 328 p. [in Ukrainian]

Kurs, (1942). Kurs providnyts dytiachykh sadkiv [Course of kindergarten leaders]. Ukrainskyi holos, 21 travnia. [in Ukrainian]

Levchenko, I. (1943). Ukrainska domivka [Ukrainian house]. Klych, 29 chervnia. [in Ukrainian]

Lysenko, O. (2003). Dobrochynnist yak vyiav natsionalnoi solidarnosti u roky Druhoi svitovoi viiny [Charity as a manifestation of national solidarity during the Second World War]. Halychyna, 9 , 101-111. [in Ukrainian]

Pystso, V. (2009). Mistsevi instytutsii samodopomohy na Rivnenshchyni v umovakh nimetskoho okupatsiinoho rezhymu [Local self-help institutions in the Rivne region under the German occupation regime]. Istorychni studii Volynskoho natsionalnoho universytetu imeni Lesi Ukrainky, 2, 15-20. [in Ukrainian]

Pro dopomohu, (1942). Pro dopomohu bidnym v Lutsku [About helping the poor in Lutsk]. Volyn, 1 zhovtnia. [in Ukrainian]

Rivnenskyi, (1943). Rivnenskyi Ukrainskyi komitet samodopomohy pratsiuie [Rivne Ukrainian Self-help Committee is working]. Volyn, 6 travnia. [in Ukrainian]

Snyder, T. (2011). Kryvavi zemli: Yevropa mizh Hitlerom i Stalinom [Bloodlands: Europe between Hitler and Stalin]. Kyiv, 446 p. [in Ukrainian]

Stelnykovych, S. (2013). Sotsialnyi zakhyst naselennia na Zhytomyrshchyni u period natsystskoi okupatsii [Social protection of the population in Zhytomyr region during the Nazi occupation]. Hileia, 73, 40-42. [in Ukrainian]

Stefaniuk, H. V. (2014). Suspilna dopomoha ukraintsiam Halychyny v period natsystskoho "novoho poriadku" (1941 - 1944 rr.) [Public assistance to Galicia's Ukrainians during the Nazi "New Order" (1941 - 1944)]. In Borotba za Ukrainu v 1943 - 1944 rr.: vlada, zbroini syly, suspilstvo (pp. 391-399). [in Ukrainian]

Ukrainskyi, (1942). Ukrainskyi dopomohovyi komitet u Lutsku [Ukrainian Aid Committee in Lutsk]. Ukrainskyi holos, 12 liutoho. [in Ukrainian]

Shaikan, V. (2005). Kolaboratsionizm na terytorii reikhskomisariatu "Ukraina" $i$ viiskovoi zony $v$ roky Druhoi svitovoi viiny [Collaboration on the territory of the Reich Commissariat "Ukraine" and the Military Zone during the Second World War]. Kryvyi Rih, 451 p. [in Ukrainian]

The article was received on July 11, 2019.

Article recommended for publishing 26/02/2020. 